\author{
Самофратова B.A. \\ кандидат економічних наук, доцент \\ кафедра економіки промисловості \\ E-mail: vica_samofatova@mail.ru \\ Карпенко В.A. \\ магістрант \\ кафедра економіки промисловості \\ Одеська національна академія харчових технологій \\ вул. Канатна, 112, м. Одеса, Україна, 65039 \\ E-mail: veronakarpenko1993@mail.ru
}

\title{
РИНКОВА СТРАТЕГІЯ РОЗВИТКУ ПІДПРИЕМСТВ РИБОПЕРЕРОБНОЇ ГАЛУЗІ УКРАЇНИ
}

В статті розглянуто сучасний стан, особливості та тенденції розвитку рибопереробної галузі України. Під час проведення аналізу було отримано дані, що свідчать про необхідність конкретних дій для подолання кризового стану підприємств досліджуваної галузі. Виявлено резерви та перспективи подальшого розвитку, а також сорормована та запропонована ринкова стратегія розвитку підприємств рибопереробної галузі України.

Ключові слова: рибопереробна галузь, марикультура, рибництво, аквакультура, стратегія розвитку, стратегічні цілі.

Постановка проблеми та їі зв'язок 3 важливими науковими і практичними завданнями. Рибне господарство України представляє собою галузь економіки, задачею якої є вивчення, вирощування, відтворення, охорона та використання риби та інших водних живих ресурсів, їх отримання (вилов, добування, збирання) та подальша переробка з метою одержання харчової, кормової, технічної, медичної та іншої продукції для задоволення потреб населення. Рибопереробна галузь надає країні цінний і часто незамінний продукт харчування, що забезпечує потребу людини насамперед у білках тваринного походження, різноманітті біологічно активних речовин, а також широкому спектрі вітамінів та мікроелементів. Проте сьогодні рибопереробна галузь України перебуває у скрутному становищі, тому проблема забезпечення ii ефективного функціонування $є$ вкрай актуальною. Ї̈і відродження необхідно розпочати 3 рішучих заходів щодо формування ринкової стратегії розвитку підприємств рибопереробної галузі України.

Аналіз останніх публікацій 3 проблеми. Проблемам стратегічного розвитку рибної галузі присвячені роботи відомих вітчизняних вчених, а саме В.М. Степанова, О.М. Багрова, П.П. Борщевського, А.А. Шевченко, А.В. Загороднюк [5], Алимова С.I [1] та інших дослідників. Однак невирішеними залишаються стратегічні проблеми розвитку рибопереробної галузі України на тривалу перспективу, що i зумовлює актуальність даної статті.
Формулювання мети дослідження. Метою статті $\epsilon$ аналіз сучасного стану та стратегічного потенціалу розвитку рибопереробної галузі України.

Виклад основних результатів та їх обгрунтування. Рибопереробна галузь України відіграє значну роль у забезпеченні населення продовольством, а галузей національної економіки - сировиною, а також у відтворенні природних ресурсів та підвищенні зайнятості населення. Нині, через різке скорочення обсягів фінансування, у рибництві наявні загрозливі тенденції. Насамперед це пов'язано 3 погіршенням технічного стану обладнання, швидкими темпами його фізичного та морального старіння та виходом 3 ладу основних фондів традиційних рибопереробних підприємств України і т.ін. Рентабельність рибного виробництва скорочується у зв'язку з постійно зростаючими витратами, необхідними для вилову риби, та, особливо, через виснаження морських рибних запасів [8].

На початку 90-х років, Україна мала в своєму розпорядженні потужну виробничу базу в галузі рибного господарства: сучасний чисельний океанічний флот, рибопереробні заводи, промисел АзовоЧорноморського басейну, рибокомбінати, вилов риби у внутрішніх водоймах Дніпровського каскаду водосховищ [4]. Проте з часом цей потенціал став втрачати свої позиції. Починаючи з 1995 року, добування біоресурсів складало близько 400,1 тис. т, а станом на 2013 рік - лише 225,8 тис. т, що майже у двічі менше (рис. 1) [9]. 


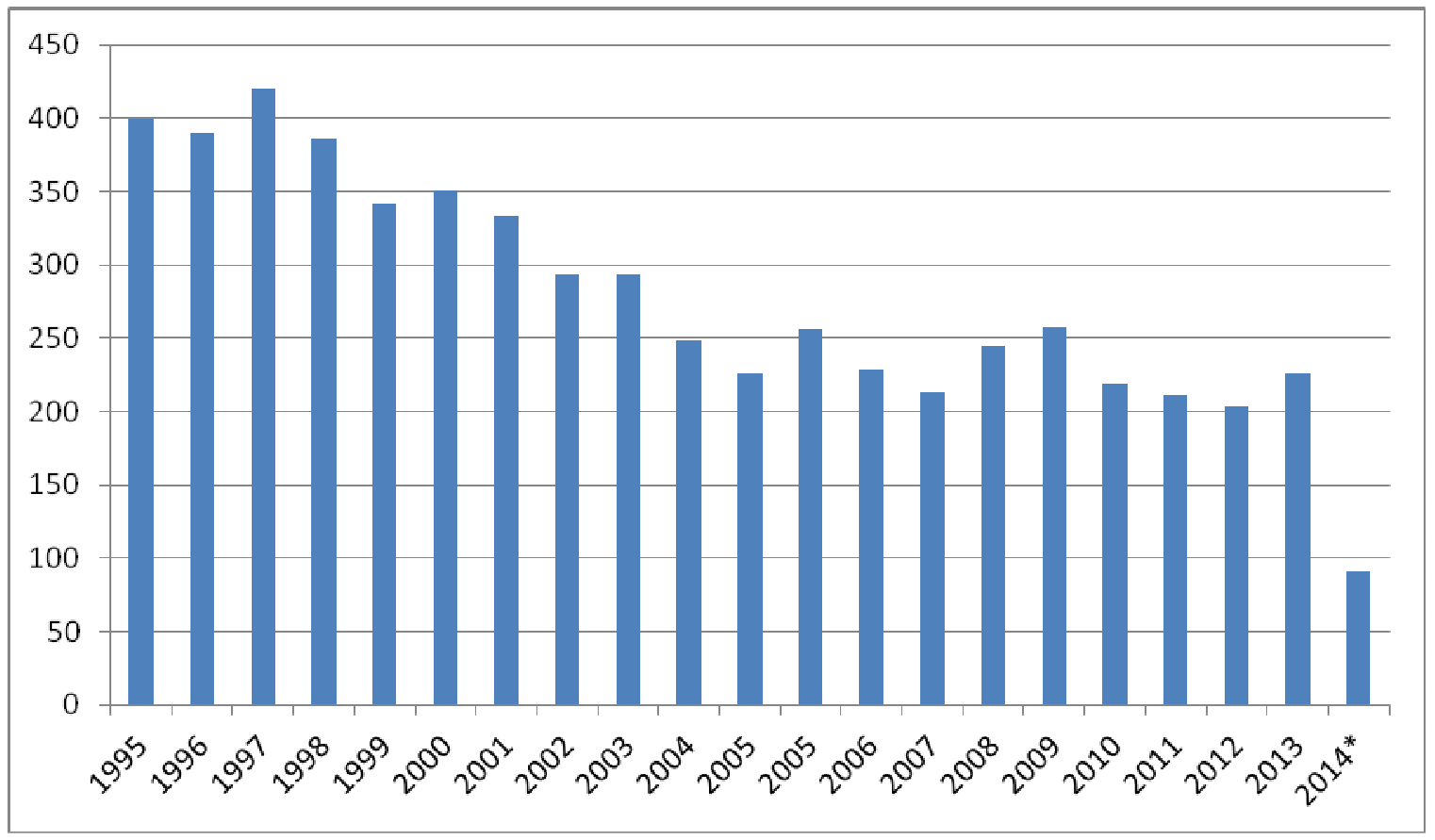

2014*- Без урахування тимчасово окупованої території Автономної Республіки Крим і м.Севастополя Рис. 1. Динаміка добування водних біоресурсів в країні та на території морських економічних зон України, тис. тонн

На початку 90-тих років рибний ринок України складався 3 продукції вітчизняних виробників майже на $95 \%$ і лише 5\% припадало на імпорт, однак зараз ситуація виглядає протилежним чином. Сьогодні національний рибний ринок складається $385 \%$ імпортної рибної продукції і лише на $15 \%$ - 3 вітчизняної [5]. Імпортна продукція переважно надходить 3 таких країн, як Норвегія, Ісландія, Канада (свіжозаморожена риба); Естонія, Росія та Латвія (рибна консервація). У сегменті свіжої та замороженої риби частка Норвегії в українському імпорті досягає 92-94\% [3].

На даний момент спостерігається ряд факторів, діяльність яких призводить до негативних наслідків в рибопереробній галузі в цілому. У зв'язку з анексією Криму Україна втратила дві третини свого вилову риби. Зокрема, у 2013 році Україна виловила 216 тис. тонн риби. При цьому 82 тис. тонн було виловлено в Азово-Чорноморському басейні, з яких 52 тис. тонн - кримськими рибалками, що становило орієнтовно $65 \%$ вилову риби в регіоні. На додачу, 98 тис. тонн риби було виловлено чорноморським флотом у світовому океані, а це $100 \%$ вилову в океанських водах. Якщо додати ці цифри, то на частку Криму припадає близько 150 тис. тонн, а це дві третини всього вилову. На фоні першої проблеми випливає і друга, а саме - збільшується обсяг імпорту риби.

Подорожчання на внутрішньому ринку. Через те, що обсяг імпортної продукції досить значний, виявляється високий рівень залежності цін на рибу в Україні від коливань іноземних валют. Вже зараз простежується збільшення цін виробників на рибні консерви (станом на лютий 2015 року в переробці та консервуванні риби, ракоподібних і молюсків продукція подорожчала орієнтовно на 55\% у зв'язку з ростом валютного курсу, інфляції та нестабільної ситуації в країні). Нестабільність в країні вже на початку року помітна, про що свідчать дані Держкомстату України відносно добування водних біоресурсів (різке зниження у січні-лютому в порівнянні з відповідним періодом 2013 року [7].

Bсі ці негативні фактори унеможливлюють ефективний розвиток рибопереробної галузі, адже безпосередньо впливають на стан попиту на рибну продукцію. Для нівелювання зазначених негативних факторів розвитку потрібно залучитися підтримкою держави та звернути увагу на необхідність застосування стратегічного планування. Стратегічне планування розвитку рибогосподарського комплексу України має враховувати глобальні зміни умов здійснення рибогосподарської діяльності. За оцінкою фахівців, у XXI сторіччі світове рибальство, як і рибальство окремих країн, буде розвиватися під впливом таких провідних чинників:

- коливання чисельності найбільш масових об'єктів промислу в залежності від глобальних кліматичних змін;

- використання недоосвоєних промислів масових пелагічних видів гідробіонтів (ставриди, сардини, анчоусу, крилю та ін.);

- жорстка конкуренція за сировинні ресурси і ринки збуту рибних товарів;

- прискорений розвиток аквакультури у внутрішніх природних і штучних водоймах, а особливо фермерства, у прибережній морській смузі та у виключних економічних зонах країн; 
- вихід експериментальної марикультури за межі економічних зон - у відкриту частину Світового океану;

- активізація природоохоронного руху за закриття для рибальства ділянок в різних акваторіях Світового океану;

- націоналізація морських водних біоресурсів і повсюдне регулювання рибальства у відкритих районах Світового океану, уведення жорсткого міжнародного контролю за промислом;

- форсоване прийняття нових міжнародних правових документів (конвенцій, кодексів, угод i т.ін.), що мають обов'язковий або строго рекомендаційний характер для всіх держав, які використовують морські живі ресурси у своїх економічних зонах та у відкритих районах Світового океану [6].

Рибогосподарська діяльність реалізується в рамках відповідних суб'єктів господарювання і покликана задовольняти потреби суспільства у рибі та рибній продукції, має два рівні управління (рівень підприємства і державний рівень), що характеризуються певними цілями та механізмами їх досягнення Першочерговою стратегічною метою державного управління рибним господарством як галуззю національної економіки є забезпечення продовольчої безпеки країни. Стратегічні цілі означають бажаний результат рибогосподарської діяльності на рівні як держави, так і окремих суб'єктів господарювання [2].

В якості основної базисної стратегії можна запропонувати стратегію концентричної диверсифікації. Суть даної стратегії полягає в тому, що економічний розвиток здійснюється за рахунок розвитку таких галузевих секторів: рибальства та аквакультури (рибництва), в складі якої виділяється марикультура молодий і перспективний для України напрямок рибогосподарської діяльності. Марикультура - розведення та вирощування морських риб та інших водних живих ресурсів у спеціально створених штучних умовах або визначених для цього ділянках прибережної смуги моря. Аквакультура - розведення та вирощування риби та інших водних живих ресурсів у спеціальних штучних умовах або визначених для цього рибогосподарських водних об'єктах [10]. Переваги марикультури (морського рибництва) у порівнянні 3 видобутком дикої риби складаються в меншій собівартості виробництва одиниці продукції, можливості управляти смаковими якостями, нівелюванні фактора сезонності рибальства і т.ін. Продукти марикультури $\epsilon$ величезним резервом для одержання цінного харчового білка, лікувально-профілактичних препаратів, кормових добавок, стимуляторів для тваринництва й інших цілей. Розвиток марикультури для України може стати вагомим фактором, що поліпшить загальний стан досліджуваної галузі. Як варіант, пропонується звернути увагу на вирощування таких представників марикультури, як мідії, устриці, креветки, рапани тощо. Вирощуванню цих гідробіонтів сприяють зручні фізико-географічні умови Одеської, Миколаївської та Херсонської областей. Стратегія передбачає створення штучних умов (ферм), котрі будуть спеціалізуватися на вирощуванні мідій, устриць та креветок.

Можна застосувати стратегію інтегрованого росту (вертикальної диверсифікації), що передбачає створення рибопереробних потужностей. Також, як варіант, можна звернути увагу на внутрішнє рибництво, якщо держава передасть його у приватну власність.

Проте існує ряд факторів, що унеможливлюють втілення даної стратегії у життя, а саме, нестабільна ситуація в країні. Лише подолавши цю проблему, можна перейти до проблем рибопереробної галузі, розвиток якої неможливий без державної підтримки.

Висновки і перспективи подальших досліджень. Україна багата на природні ресурси та володіє достатніми умовами для розвитку рибопереробної галузі, проте невміння правильно використовувати ресурси та недостатність державної підтримки в цілому негативно вплинули на іï розвиток. У зв'язку 3 цим виникає необхідність застосування рішучих дій по розробці ринкової стратегії розвитку підприємств рибопереробної галузі України. Слід зазначити, що покращення ситуації можливе лиже за рахунок комплексного підходу до зазначеної проблеми. Надані рекомендації можуть покращити стан рибопереробної галузі та допоможуть їй перейти на новий етап розвитку, що сприятливо позначиться на забезпеченні населення імпортозамінною рибною продукцією.

\section{Література}

1. Алимов С. І. Рибне господарство України: стан і перспективи / С. І. Алимов. - К. : Вища освіта, 2003. -335 c.

2. Виханский О. С. Стратегическое управление : учеб. [2-е изд., перераб. и доп.] / О. С. Виханский. - М. : Экономистъ, 2004. - 296 с.

3. Ганжуренко I. В. Сучасний стан і розвиток рибопромислового підкомплексу України та світу / I. В. Ганжуренко // Вісник Одеського національного університету. - № 18. Вип. 3/1. - 2013. - С. $72-78$.

4. Горшунов М. С. Розробка технології виробництва пресервів та рибних консервів з використанням лактоферментованої сировини. Автореферат дис. ... к.т.н. : 05.18 .04 - Технологія м'ясних, молочних та рибних продуктів. - Одеса - 2007. - 22 с.

5. Загороднюк О. В. Формування та розвиток ринку риби і рибної продукції України. Автореферат дис. ... к.е.н. : 08.00.03 - Економіка і управління національним господарством. - Одеса - 2012. - 24 с.

6. Козій С. Перспективи розвитку ринку риби і рибної продукції // Экономические инновации. Вып. 19: Приоритеты преобразований в экономике. Сборник научных работ. - Одесса : Институт проблем рынка и экономико-экологических исследований НАН Украины, 2004. - С. 230-236. 
7. Смольникова А. В. Рыбное место. Обзор рынка / А. В. Смольникова // Мир продуктов. - № 4 (63). 2011. - C. $34-39$.

8. Самофатова В. А. Аналіз перспектив розвитку рибопереробної галузі України / В. А. Самофатова, Г. І. Фалюта // Економіка харчової промисловості. - 2014. - № 3(23). - С. 50-52.

9. Офіційний сайт Державного комітету статистики України. http://ukrstat.gov.ua.

10. Закон України «Про Загальнодержавну програму розвитку рибного господарства України на період до 2010 року». [Електронний ресурс] - Режим доступу: http://zakon2.rada.gov.ua/laws/show/1516-15.

Стаття надійшла 22.03.2015

\author{
Самофатова В.A. \\ кандидат экономических наук, доцент \\ E-mail: vica_samofatova@mail.ru \\ Карпенко В.A. \\ магистрант \\ кафедра экономики промышленности \\ Одесская национальная академия пищевых технологий \\ ул. Канатная, 112, м. Одеса, Украина, 65039 \\ E-mail: veronakarpenko1993@mail.ru
}

\title{
РЫНОЧНАЯ СТРАТЕГИЯ РАЗВИТИЯ ПРЕДПРИЯТИЙ РЫБОПЕРЕРАБАТЫВАЮЩЕЙ ОТРАСЛИ УКРАИНЫ
}

В статье рассмотрены современное состояние, особенности и тенденции развития рыбоперерабатывающей отрасли Украины. Во время проведения анализа были получены данные, свидетельствующие о необходимости конкретных действий для преодоления кризисного состояния предприятий представленной отрасли. Выявлены резервы и перспективы дальнейшего развития, а также сорормирована и предложена рыночная стратегия развития предприятий рыбоперерабатывающей отрасли Украины.

Рыбоперерабатывающая отрасль предоставляет стране ценный и часто незаменимый продукт питания, который обеспечивает потребность человека, прежде всего в белках животного происхождения, многообразии биологически активных веществ, а также широком спектре витаминов и микроэлементов. Однако сегодня рыбоперерабатывающая отрасль Украины находится в трудном положении. Ее возрождение и дальнейшее развитие необходимо начать с решительных мер по формированию рыночной стратегии развития предприятий рыбоперерабатывающей отрасли Украины. Для решения проблемы была предложена стратегия концентрической диверсификации. Суть данной стратегии состоит в том, что экономическое развитие осуществляется за счет развития таких отраслевых секторов: рыболовства и аквакультуры (рыбоводства), в составе которых выделяется марикультура - молодое и перспективное для Украины направление рыбохозяйственной деятельности.

Преимущества марикультуры (морского рыбоводства), по сравнению с добычей дикой рыбы, состоят в меньшей себестоимости производства единицы продукции, возможности управлять вкусовыми качествами, нивелировании фактора сезонности рыболовства и т.п. Продукты марикультуры являются огромным резервом для получения ценного пищевого белка, лечебно-профилактических препаратов, кормовых добавок, стимуляторов для животноводства и других целей. Представленные рекомендации могут улучшить состояние рыбоперерабатывающей отрасли и помогут ей перейти на новый этап развития, что благоприятно скажется на продовольственной безопасности страны.

Ключевые слова: рыбоперерабатывающая отрасль, марикультура, рыбоводство, аквакультура, стратегия развития, стратегические цели. 


\author{
Samofatova V.A. \\ Ph.D., Associate Professor \\ Department of Industrial Economics \\ E-mail: vica_samofatova@mail.ru \\ Odessa National Academy of Food Technologies \\ Kanatna str., 112, Odessa city, Ukraine, 65039 \\ Karpenko V.A. \\ Undergraduate \\ Department of Industrial Economics \\ E-mail: veronakarpenko1993@mail.ru \\ Odessa National Academy of Food Technologies \\ Kanatna str., 112, Odessa city, Ukraine, 65039
}

\title{
THE MARKET DEVELOPMENT STRATEGY FISH PROCESSING INDUSTRY IN UKRAINE
}

In the article the current status, characteristics and trends of fish processing industry in Ukraine. During the analysis of the data was obtained, indicating the need for concrete actions to overcome crisis companies represented industry. Discovered reserves and prospects for further development, and formed and proposed market development strategy fish processing industry in Ukraine. Fish processing industry gives the country a valuable and often irreplaceable food that provides human need first of all proteins of animal origin, variety of biologically active substances, as well as a wide range of vitamins and minerals.

However the current state of the fish processing industry in Ukraine is in a difficult situation, which is a very urgent problem today. Its revival and further development is necessary to start with decisive measures to create a market development strategy for enterprises fish processing industry in Ukraine. To solve the problem, it was suggested concentric diversification strategy. The essence of this strategy is that economic development at the expense of such industry sectors: fisheries and aquaculture (fish farming), which included distinguished mariculture - young and promising direction for Ukraine fisheries activities.

Benefits mariculture (marine fish farming) compared to wild prey fish up to a lesser unit production cost, the possibility to control taste, leveling factor seasonal fishing and so on. Products mariculture is a huge reserve for obtaining valuable dietary protein, health care drugs, feed additives, stimulants for livestock and other purposes. The development of mariculture for Ukraine could be an important factor in improving the general condition of the field provided. The recommendations can improve the fish processing industry and help it move to a new phase of development that will benefit the food security of the country.

Keywords: fish processing industry, mariculture, fish farming, aquaculture, strategy development, strategic goals.

\section{References}

1. Alymov S.I. (2003). Rybne hospodarstvo Ukrainy: stan i perspektyvy. K.: Vyshcha osvita, 335.

2. Vykhanskyi O.S. (2004). Stratehycheskoe upravlenye : ucheb. M.: Ekonomyst, 296.

3. Hanzhurenko I.V. (2013). Suchasnyi stan i rozvytok rybopromyslovoho pidkompleksu Ukrainy ta svitu. Visnyk Odeskoho natsionalnoho universytetu. № 18. Vyp. 3/1, 72-78.

4. Horshunov M.S. (2007). Rozrobka tekhnolohii vyrobnytstva preserviv ta rybnykh konserviv z vykorystanniam la-ktofermentovanoi syrovyny. Avtoreferat dys. ... k.t.n. : 05.18.04 - Tekhnolohiia miasnykh, molochnykh ta rybnykh produktiv. Odesa, 22.

5. Zahorodniuk O.V. (2012). Formuvannia ta rozvytok rynku ryby i rybnoi produktsii Ukrainy. Avtoreferat dys. k.e.n.: 08.00.03 - Ekonomika i upravlinnia natsionalnym hospodarstvom. Odesa, 24.

6. Kozii S. (2004). Perspektyvy rozvytku rynku ryby i rybnoi produktsii. Ekonomycheskye ynnovatsyy. Vyp. 19: Pryorytety preobrazovanyi v ekonomyke. Sbornyk nauchnykh rabot. Odessa: Ynstytut problem rynka i ekonomykoekolohycheskykh yssledovanyi NAN Ukrayny, 230-236.

7. Smolnykova A.V. (2011). Rybnoe mesto. Obzor rynka. Myr produktov, № 4 (63), 34-39.

8. Samofatova V.A., Faliuta H.I. (2014). Analiz perspektyv rozvytku rybopererobnoi haluzi Ukrainy. Ekonomika kharchovoi promyslovosti. № 3(23), 50-52.

9. Ofitsiinyi sait Derzhavnoho komitetu statystyky Ukrainy. http://ukrstat.gov.ua.

10. Zakon Ukrainy «Pro Zahalnoderzhavnu prohramu rozvytku rybnoho hospodarstva Ukrainy na period do 2010 roku». [Elektronnyi resurs]. Rezhym dostupu: http://zakon2.rada.gov.ua/laws/show/1516-15. 